\title{
RESEARCH
}

Open Access

\section{Effect of thinning intensity on understory herbaceous diversity and biomass in mixed coniferous and broad-leaved forests of Changbai Mountain}

Gerong Wang ${ }^{1 \dagger}$, Yue Sun ${ }^{2+}$, Mo Zhou', Naiqian Guan ${ }^{1}$, Yuwen Wang ${ }^{1}$, Runhua Jiang ${ }^{1}$, Zhiyu Liu', Mengjia Wu ${ }^{1}$ and Fucai $\mathrm{Xia}^{1 *}$

\begin{abstract}
Background: Herbs are an important part of the forest ecosystem, and their diversity and biomass can reflect the restoration of vegetation after forest thinning disturbances. Based on the near-mature secondary coniferous and broad-leaved mixed forest in Jilin Province Forestry Experimental Zone, this study analyzed seasonal changes of species diversity and biomass of the understory herb layer after different intensities of thinning.

Results: The results showed that although the composition of herbaceous species and the ranking of importance values were affected by thinning intensity, they were mainly determined by seasonal changes. Across the entire growing season, the species with the highest importance values in thinning treatments included Carex pilosa, Aegopodium alpestre, Meehania urticifolia, and Filipendula palmata, which dominated the herb layer of the coniferous and broad-leaved mixed forest. The number of species, Margalef index, Shannon-Wiener index and Simpson index all had their highest values in May, and gradually decreased with months. Pielou index was roughly inverted " $\mathrm{N}$ " throughout the growing season. Thinning did not increase the species diversity. Thinning can promote the total biomass, above- and below-ground biomass. The number of plants per unit area and coverage were related to the total biomass, above- and below-ground biomass. The average height had a significantly positive correlation with herb biomass in May but not in July. However, it exerted a significantly negative correlation with herb biomass in September. The biomass in the same month increased with increasing thinning intensity. Total herb biomass, above- and below-ground biomass showed positive correlations with Shannon-Winner index, Simpson index and Pielou evenness index in May.

Conclusions: Thinning mainly changed the light environment in the forest, which would improve the plant diversity and biomass of herb layer in a short time. And different thinning intensity had different effects on the diversity of understory herb layer. The findings provide theoretical basis and reference for reasonable thinning and tending in coniferous and broad-leaved mixed forests.
\end{abstract}

Keywords: Selective thinning, Mixed coniferous and broad-leaved forests, Herbaceous plants, Diversity, Biomass

\footnotetext{
* Correspondence: xfc0707@163.com

${ }^{\dagger}$ Gerong Wang and Yue Sun are authors contributed equally to this work and should be considered as co-first authors.

'Key Laboratory of State Forestry Administration on Conservation and Efficient Utilization of Precious and Rare Forest Resource in Changbai

Mountain, Forestry College, Beihua University, 132013 Jilin, China

Full list of author information is available at the end of the article
}

(c) The Author(s). 2021 Open Access This article is licensed under a Creative Commons Attribution 4.0 International License which permits use, sharing, adaptation, distribution and reproduction in any medium or format, as long as you give appropriate credit to the original author(s) and the source, provide a link to the Creative Commons licence, and indicate if changes were made. The images or other third party material in this article are included in the article's Creative Commons licence, unless indicated otherwise in a credit line to the material. If material is not included in the article's Creative Commons licence and your intended use is not permitted by statutory regulation or exceeds the permitted use, you will need to obtain permission directly from the copyright holder. To view a copy of this licence, visit http://creativecommons.org/licenses/by/4.0/. 


\section{Background}

Understory herbaceous plants are an important part of the species diversity of forest ecosystems (Han et al. 2016). In temperate forests, more than $80 \%$ of vascular plants are herbaceous plants (Whigham 2004), and herbaceous plants are of great significance for maintaining the species diversity of forest ecosystems. Compared with trees and shrubs, understory herbs are more sensitive to disturbances and are the most adaptable to the environment. If the disturbance severely destroys the original forest ecosystem, herbaceous plants will usually recover fast, thereby quickly improving the soil site conditions, reducing the intensity of solar radiation on the ground, and providing important protection for the regeneration of trees and shrubs and the growth of seedlings (Huang et al. 2016). Therefore, the species diversity and biomass of the herb layer can reflect the vegetation restoration status after forest disturbance.

Forest thinning is an important disturbance in the forest managements. Thinning can have an important impact on the stability of the forest ecosystem, and even destroy the balance of the forest ecosystem (Lei et al. 2005). As an important disturbance in the forest managements, thinning has long attracted people's attention (Zhou et al. 2012). Reasonable thinning can maintain the stability and structure of the forest ecosystem while obtaining timber, and achieve sustainable forest management (Zhou et al. 2015). Thinning can affect forest growth, understory vegetation regeneration, forest spatial structure, forest species diversity (Rong et al. 2014; You et al. 2015; Gong et al. 2015; Huang 2016). Some studies have reported that thinning can not only promote the growth of tree height and diameter at breast height, increase forest stock and improve wood quality (An et al. 2012), but also improve the understory environment, reduce understory competition among species, and promote the increase in the growth and diversity of understory species, especially the understory herb layer (Li et al. 2012).

Due to long-term human disturbance, the original broad-leaved Korean pine forests in Northeast China have been severely damaged, and now there are a large number of secondary coniferous and broad-leaved mixed forests (Zhang et al. 2009). Reasonable thinning can accelerate the succession rate of this forest type, realize its sustainable management, and play an important role in maintaining the stability of timber yield and species diversity (Liu et al. 2014). Through thinning of different intensities in the near-mature secondary coniferous and broad-leaved mixed forest in the State-owned Forest Protection Center of the Jilin Province Forestry Experimental Zone, this study investigated the species diversity and the seasonal changes of biomass of the understory herb layer after thinning, and evaluated the influence of thinning on herbaceous plants. The study aims to provide a theoretical basis for reasonable tending and thinning for secondary coniferous and broad-leaved mixed forests in Northeast China.

\section{Materials and methods \\ Study area}

The study site was located at Dapo Forest Farm (43⒌ ${ }^{\prime} \mathrm{N}$, $\left.127^{\circ} 43^{\prime} \mathrm{E}\right)$, the state-owned forest protection center of Jilin Province Forestry Experimental Zone. In July 2011, 4 permanent monitoring plots with an area of 1 ha $(100 \mathrm{~m} \times$ $100 \mathrm{~m}$ ) were set up in the near-mature forest. Each plot was divided into 25 plots of $20 \mathrm{~m} \times 20 \mathrm{~m}$ and the forest stand survey was conducted. In December 2012, 4 plots were thinned with actual intensity of $0,17.2 \%, 32.7 \%$, and $50.8 \%$ respectively, which were defined as unthinning (CK), light thinning (LT), moderate thinning (MT) and heavy thinning (HT) (Liu et al. 2019).

\section{Herbaceous plant diversity}

At the beginning of May 2015, 4 herbal plots of $1 \mathrm{~m} \times 1 \mathrm{~m}$ were randomly set up in each $20 \mathrm{~m} \times 20 \mathrm{~m}$ plot, and a total of 100 herbal plots were set up. From early May to early October 2015, the species name, abundance, average height, and coverage of the herb plots in the four plots were investigated, and the total coverage was also recorded. The relative abundance (RA), relative coverage (RC), relative height $(\mathrm{RH})$, and importance value (IV) of herbaceous plants based on the obtained data were calculated. Furthermore, the Margalef index $(R)$, Shannon-Wiener index $(H)$, Simpson index $(D)$ and Pielou index (Jsw) were also calculated as follows:

Importance value: $\mathrm{IV}=\frac{(\mathrm{RA}+\mathrm{RC}+\mathrm{RH})}{3}$

Margalef index: $R=\frac{(S-1)}{\ln N}$

Shannon - Wiener index: $H^{\prime}=-\sum_{i=1}^{S}\left(P_{i} \times \ln P_{i}\right)$

$$
\text { Simpson index: } D=1-\sum_{i=1}^{S} P_{i}^{2}
$$

Pielou index: Jsw $=\frac{-\sum_{i=1}^{S}\left(P_{i} \times \ln P_{i}\right)}{\ln S}$

where IV is the importance value, RA is the relative abundance, $\mathrm{RC}$ is the relative coverage, $\mathrm{RH}$ is the relative height, $S$ is the total number of species in the sample plot, $N$ is the total individuals of species in the sample plot, and $N_{i}$ is the individual of the $i$-th species Number, 
$P_{i}$ is the relative value of $i$, and the calculation formula of $P_{i}$ is:

$$
P_{i}=\frac{N_{i}}{N}
$$

\section{Herbaceous plant biomass}

In early May, mid-July, and early September 2015, the understory herbaceous biomass was sampled and surveyed three times. Specifically, two $1 \mathrm{~m} \times 1 \mathrm{~m}$ subplots were randomly set up in each $20 \mathrm{~m} \times 20 \mathrm{~m}$ plot. We investigated all species names, abundance, height, coverage, total coverage, and finally harvested the whole plant for all the herbs in the subplot. The samples were taken back to the laboratory to clean the soil at the roots with water. The above- and belowground parts were cut with scissors, and weighed their fresh weight (MA for aboveground part and $\mathrm{MB}$ for belowground part). Then the sample was first quenched at $105^{\circ} \mathrm{C}$ for $30 \mathrm{~min}$, adjusted to $85{ }^{\circ} \mathrm{C}$ and dried to a constant weight. After drying, weigh the dry weight of the aboveground and belowground parts and record them as WA and WB. The herb biomass of the entire subplot was calculated based on the coverage, the dry weight of the herbaceous plants, and the area of the entire subplot (Sun et al. 2017).

\section{Data analysis}

Correlation analysis and one-way analysis of variance (one-way ANOVA) were performed to test thinning effects on herbaceous diversity and biomass. A total of $1001 \mathrm{~m} \times 1 \mathrm{~m}$ herbal plots in each thinning treatment was defined as replicates. Multiple comparisons were performed using the least significant difference method (LSD) once the thinning effects were significant. All data analysis was performed using SPSS18.0 software. The significance level was set at $\alpha<0.05$.

\section{Results \\ Effect of thinning on plant diversity Species composition}

During the whole growing season, a total of 87 species of herbaceous plants were investigated in 4 plots, belonging to 37 families and 74 genera. From the distribution of each family, the number of species belonging to Ranunculaceae, Liliaceae, Umbelliferae and Compositae was the largest, with $11,7,7$ and 5 species respectively. There were 19 families containing only one species and 8 families including 2 species. Only 2 families (Rosaceae and Papaveraceae) included 3 species. Four families (Cyperaceae, Rubiaceae, Caryophyllaceae and Urticaceae) included 4 species, accounting for $10.8 \%$ of all families.

From the distribution of the genera, there are 64 genera with 1 species, accounting for $86.5 \%$ of the total number of genera. There are 10 genera with more than
2 species, accounting for $13.5 \%$ of the total number of genera. Among them, there are 7 genera (Lilium, Viola, Geranium, Hippochaete, Cimicifuga, Arisaema and Anemone) containing 2 species and 3 genera (Rubia, Carex, and Urtica) containing 3 species. In summary, a single family and a single genus had an absolute advantage in the survey plots, and the phenomenon of few families and few genera was obvious, which was a typical species distribution of temperate forest herbs.

Compared with the control, thinning increased the number of species and genera of herbaceous plants. Light thinning, moderate thinning and heavy thinning increased 2 species and 3 genera, 8 species and 9 genera, 1 species and 1 genus, respectively. For the family, moderate thinning increased 1 family, while light thinning and heavy thinning both decreased by 1 family compared with the control (Table 1).

The number of species, genera and families of herbaceous plants in each thinning treatment showed seasonal variations. In May, the number of species, genera and families in the thinning were higher than those of the control, and the number of species, genera and families in the heavy thinning plot was the largest. In June, the number of species, genera and families in the thinning were all low compared with the control, and light thinning had the smallest number of species, genera and families. In July, August and September, moderate thinning had the largest number of species, genera and families while heavy thinning was opposite. In October, the number of herbaceous species in each plot decreased sharply, with little difference among thinning treatments. The number of species in the control and moderate thinning was slightly higher than that of light thinning and heavy thinning.

\section{Seasonal variation of importance values}

The importance values of herbaceous plants in different thinning in each month are shown in Table 2. In May, the top 5 importance values of herbaceous plants in the control were Anemone raddeana, Hylomecon japonica, Aegopodium alpestre, Meehania urticifolia and Corydalis ambigua. The sum of the importance values of these plants was $51.38 \%$, dominating in the plot. Among them, there were 15 species with importance values greater than $1 \%$, and the sum of their importance values accounted for $93.54 \%$ of all herb species. Carex pilosa, Anemone raddeana, Filipendula palmata, Meehania urticifolia, and Cardamine leucantha were the top 5 importance values of herbaceous plants in the light thinning, with the sum of the importance values of $51.21 \%$. There are 14 species of herbs with importance value greater than $1 \%$, and the sum of their importance values accounted for $88.35 \%$ of all herb species. Carex 
Table 1 Changes in the number of families, genera and species of herbaceous plants in each thinning treatment in different months

\begin{tabular}{|c|c|c|c|c|c|c|c|c|c|c|c|c|}
\hline \multirow[t]{2}{*}{ Month } & \multicolumn{3}{|l|}{ CK } & \multicolumn{3}{|l|}{ LT } & \multicolumn{3}{|l|}{ MT } & \multicolumn{3}{|l|}{ HT } \\
\hline & Species & Genus & Family & Species & Genus & Family & Species & Genus & Family & Species & Genus & Family \\
\hline May & $36 \pm 2$ & $34 \pm 0$ & $18 \pm 0$ & $43 \pm 3$ & $39 \pm 1$ & $24 \pm 0$ & $44 \pm 3$ & $40 \pm 1$ & $21 \pm 0$ & $44 \pm 3$ & $41 \pm 1$ & $25 \pm 0$ \\
\hline June & $37 \pm 2$ & $36 \pm 1$ & $25 \pm 0$ & $32 \pm 3$ & $30 \pm 0$ & $21 \pm 0$ & $35 \pm 2$ & $32 \pm 1$ & $22 \pm 0$ & $33 \pm 2$ & $32 \pm 1$ & $23 \pm 0$ \\
\hline July & $38 \pm 3$ & $36 \pm 1$ & $22 \pm 0$ & $39 \pm 2$ & $36 \pm 1$ & $25 \pm 0$ & $46 \pm 3$ & $40 \pm 1$ & $27 \pm 0$ & $36 \pm 3$ & $31 \pm 1$ & $21 \pm 0$ \\
\hline August & $33 \pm 2$ & $27 \pm 0$ & $20 \pm 0$ & $29 \pm 1$ & $25 \pm 0$ & $22 \pm 0$ & $36 \pm 3$ & $30 \pm 0$ & $20 \pm 0$ & $30 \pm 1$ & $26 \pm 0$ & $19 \pm 0$ \\
\hline September & $23 \pm 1$ & $21 \pm 0$ & $15 \pm 0$ & $21 \pm 0$ & $19 \pm 0$ & $15 \pm 0$ & $25 \pm 1$ & $22 \pm 0$ & $15 \pm 0$ & $14 \pm 0$ & $13 \pm 0$ & $13 \pm 0$ \\
\hline October & $10 \pm 0$ & $10 \pm 0$ & $8 \pm 0$ & $8 \pm 0$ & $7 \pm 0$ & $7 \pm 0$ & $10 \pm 0$ & $8 \pm 0$ & $7 \pm 0$ & $9 \pm 0$ & $8 \pm 0$ & $7 \pm 0$ \\
\hline Total & $65 \pm 2$ & $53 \pm 1$ & $31 \pm 0$ & $67 \pm 2$ & $56 \pm 1$ & $30 \pm 0$ & $73 \pm 3$ & $62 \pm 1$ & $32 \pm 0$ & $66 \pm 2$ & $54 \pm 1$ & $30 \pm 0$ \\
\hline
\end{tabular}

pilosa, Anemone raddeana, Filipendula palmata, Meehania urticifolia and Poa annua were the top 5 importance values of herbaceous plants in the moderate thinning. The sum of the importance values of these plants was $49.36 \%$, and there were 18 species with the importance value greater than $1 \%$ and the sum of their importance values accounted for $89.56 \%$ of all herbaceous species. Filipendula palmata, Aegopodium alpestre, Anemone raddeana, Anemone amurensis, and Meehania urticifolia were the top 5 herbaceous plants in the heavy thinning plots. The sum of the important values of these plants was $46.09 \%$. There were 17 species of herbaceous plants with the importance value greater than $1 \%$, and the sum of their importance values accounted for $89.93 \%$ of all herb species. The proportion of important value of early spring herbs (including Anemone raddeana, Anemone amurensis, Hylomecon japonica, Gagea lutea, Corydalis ambigua, Adonis amurensis, etc.) in the control was relatively high $(42.64 \%)$, while that of light thinning, moderate thinning and heavy thinning were $24.90 \%, 18.64 \%$ and $22.09 \%$ respectively, which was significantly lower than that of the control, indicating that the phenological period of herbs after thinning was advanced. Some early spring herbs in early May had completed the whole life cycle and died.

In June, the top 5 important values of herbaceous plants in the control were Carex pilosa, Poa апnиa, Meehania urticifolia, Aegopodium alpestre and Filipendula palmata. The sum of the importance values of these plants was $50.88 \%$. There were 18 species with the importance value greater than 1 , and the sum of their importance values accounted for $92.57 \%$ of all herbaceous species. The top 5 important values of herbaceous plants in the light thinning were Carex pilosa, Athyrium multidentatum, Aegopodium alpestre, Filipendula palmata and Brachybotrys paridiformis. The sum of the importance values was $59.92 \%$, and there were 16 species with the importance value greater than 1 . The top 5 importance values of herbaceous plants in the moderate thinning and heavy thinning plots were Carex pilosa, Meehania urticifolia, Carex remotiuscula, Aegopodium alpestre and Filipendula palmata, but their importance values were different. The order of importance values in the moderate thinning was Carex pilosa $>$ Meehania urticifolia $>$ Carex remotiuscula $>$ Aegopodium alpestre $>$ Filipendula palmata. The importance values of the heavy thinning were Carex pilosa $>$ Filipendula palmata $>$ Aegopodium alpestre $>$ Carex remotiuscula $>$ Meehania urticifolia. In the moderate thinning and heavy thinning, the sum of the importance values of these plants was $58.10 \%$ and $56.22 \%$, respectively. Herbs with importance values greater than $1 \%$ were 20 and 17 , and accounted for $91.30 \%$ and $91.49 \%$ of all herb species, respectively. The number of species in the control was large, because the poor light conditions in the control led to late plant phenology, and there were more early spring herbs in the control, which led to the existence of early summer herbs and early spring herbs at the same time, resulting in a large number of species; while in the thinning plot, due to the better light conditions caused by thinning, most of the early spring herbs had died, resulting in the number of species has declined.

In July, the top 5 importance values of herbaceous plants in the control were Carex pilosa, Laportea bulbifera, Filipendula palmata, Cardamine leucantha, and Meehania urticifolia. The sum of the importance values of these plants was $56.33 \%$, there were 16 species with the importance value greater than $1 \%$, and the sum of their importance values accounted for $90.20 \%$ of all herb species. The top 5 important values of herbaceous plants in the light thinning were Carex pilosa, Filipendula palmata, Aegopodium alpestre, Matteuccia struthiopteris and Anemone amurensis. The sum of the importance values of these plants was $60.67 \%$, and there were 19 species with the importance value greater than $1 \%$. The sum of their importance values accounted for $90.52 \%$ of all herb species. The top 5 important values of herbaceous plants in the moderate thinning and heavy thinning plots were Carex pilosa, Meehania urticifolia, 
Table 2 The top 5 herbs with relative importance value in different months

\begin{tabular}{|c|c|c|c|c|c|c|c|c|}
\hline \multirow[t]{2}{*}{ Month } & \multicolumn{2}{|l|}{ CK } & \multicolumn{2}{|l|}{ LT } & \multicolumn{2}{|l|}{ MT } & \multicolumn{2}{|l|}{ HT } \\
\hline & Species & $\begin{array}{l}\text { Importance } \\
\text { value (\%) }\end{array}$ & Species & $\begin{array}{l}\text { Importance } \\
\text { value (\%) }\end{array}$ & Species & $\begin{array}{l}\text { Importance } \\
\text { value (\%) }\end{array}$ & Species & $\begin{array}{l}\text { Importance } \\
\text { value (\%) }\end{array}$ \\
\hline \multirow[t]{6}{*}{ May } & $\begin{array}{l}\text { Anemone } \\
\text { raddeana }\end{array}$ & 18.11 & Carex pilosa & 18.93 & Carex pilosa & 17.53 & $\begin{array}{l}\text { Filipendula } \\
\text { palmata }\end{array}$ & 12.92 \\
\hline & $\begin{array}{l}\text { Hylomecon } \\
\text { japonica }\end{array}$ & 9.96 & $\begin{array}{l}\text { Anemone } \\
\text { raddeana }\end{array}$ & 14.47 & $\begin{array}{l}\text { Anemone } \\
\text { raddeana }\end{array}$ & 12.04 & $\begin{array}{l}\text { Aegopodium } \\
\text { alpestre }\end{array}$ & 12.32 \\
\hline & $\begin{array}{l}\text { Aegopodium } \\
\text { alpestre }\end{array}$ & 9.47 & $\begin{array}{l}\text { Filipendula } \\
\text { palmata }\end{array}$ & 8.89 & $\begin{array}{l}\text { Filipendula } \\
\text { palmata }\end{array}$ & 8.35 & $\begin{array}{l}\text { Anemone } \\
\text { raddeana }\end{array}$ & 9.38 \\
\hline & $\begin{array}{l}\text { Meehania } \\
\text { urticifolia }\end{array}$ & 7.23 & $\begin{array}{l}\text { Meehania } \\
\text { urticifolia }\end{array}$ & 4.48 & $\begin{array}{l}\text { Meehania } \\
\text { urticifolia }\end{array}$ & 7.35 & $\begin{array}{l}\text { Anemone } \\
\text { amurensis }\end{array}$ & 6.84 \\
\hline & $\begin{array}{l}\text { Corydalis } \\
\text { ambigua }\end{array}$ & 6.61 & $\begin{array}{l}\text { Cardamine } \\
\text { leucantha }\end{array}$ & 4.44 & Poa annua & 4.09 & $\begin{array}{l}\text { Meehania } \\
\text { urticifolia }\end{array}$ & 4.63 \\
\hline & Others & 48.62 & Others & 48.79 & Others & 50.64 & Others & 53.91 \\
\hline \multirow[t]{6}{*}{ June } & Carex pilosa & 14.39 & Carex pilosa & 28.14 & Carex pilosa & 26.63 & Carex pilosa & 19.29 \\
\hline & Poa annua & 9.87 & $\begin{array}{l}\text { Athyrium } \\
\text { multidentatum }\end{array}$ & 8.92 & $\begin{array}{l}\text { Meehania } \\
\text { urticifolia }\end{array}$ & 9.26 & $\begin{array}{l}\text { Filipendula } \\
\text { palmata }\end{array}$ & 10.94 \\
\hline & $\begin{array}{l}\text { Meehania } \\
\text { urticifolia }\end{array}$ & 9.87 & $\begin{array}{l}\text { Aegopodium } \\
\text { alpestre }\end{array}$ & 8.90 & $\begin{array}{l}\text { Carex } \\
\text { remotiuscula }\end{array}$ & 8.68 & $\begin{array}{l}\text { Aegopodium } \\
\text { alpestre }\end{array}$ & 10.33 \\
\hline & $\begin{array}{l}\text { Aegopodium } \\
\text { alpestre }\end{array}$ & 8.73 & $\begin{array}{l}\text { Filipendula } \\
\text { palmata }\end{array}$ & 8.07 & $\begin{array}{l}\text { Aegopodium } \\
\text { alpestre }\end{array}$ & 8.18 & $\begin{array}{l}\text { Carex } \\
\text { remotiuscula }\end{array}$ & 8.42 \\
\hline & $\begin{array}{l}\text { Filipendula } \\
\text { palmata }\end{array}$ & 8.02 & $\begin{array}{l}\text { Brachybotrys } \\
\text { paridiformis }\end{array}$ & 5.89 & $\begin{array}{l}\text { Filipendula } \\
\text { palmata }\end{array}$ & 5.35 & $\begin{array}{l}\text { Meehania } \\
\text { urticifolia }\end{array}$ & 7.24 \\
\hline & Others & 49.12 & Others & 40.08 & Others & 41.90 & Others & 43.78 \\
\hline \multirow[t]{6}{*}{ July } & Carex pilosa & 16.27 & Carex pilosa & 35.84 & Carex pilosa & 27.52 & Carex pilosa & 27.76 \\
\hline & $\begin{array}{l}\text { Laportea } \\
\text { bulbifera }\end{array}$ & 10.98 & $\begin{array}{l}\text { Filipendula } \\
\text { palmata }\end{array}$ & 9.67 & $\begin{array}{l}\text { Filipendula } \\
\text { palmata }\end{array}$ & 8.42 & $\begin{array}{l}\text { Filipendula } \\
\text { palmata }\end{array}$ & 15.34 \\
\hline & $\begin{array}{l}\text { Filipendula } \\
\text { palmata }\end{array}$ & 9.77 & $\begin{array}{l}\text { Aegopodium } \\
\text { alpestre }\end{array}$ & 5.62 & $\begin{array}{l}\text { Carex } \\
\text { remotiuscula }\end{array}$ & 7.35 & $\begin{array}{l}\text { Aegopodium } \\
\text { alpestre }\end{array}$ & 7.96 \\
\hline & $\begin{array}{l}\text { Cardamine } \\
\text { leucantha }\end{array}$ & 9.74 & $\begin{array}{l}\text { Matteuccia } \\
\text { struthiopteris }\end{array}$ & 5.21 & $\begin{array}{l}\text { Meehania } \\
\text { urticifolia }\end{array}$ & 5.92 & $\begin{array}{l}\text { Meehania } \\
\text { urticifolia }\end{array}$ & 5.55 \\
\hline & $\begin{array}{l}\text { Meehania } \\
\text { urticifolia }\end{array}$ & 9.57 & $\begin{array}{l}\text { Anemone } \\
\text { amurensis }\end{array}$ & 4.33 & $\begin{array}{l}\text { Aegopodium } \\
\text { alpestre }\end{array}$ & 5.73 & $\begin{array}{l}\text { Carex } \\
\text { remotiuscula }\end{array}$ & 3.64 \\
\hline & Others & 43.67 & Others & 39.33 & Others & 45.06 & Others & 39.75 \\
\hline \multirow[t]{6}{*}{ August } & $\begin{array}{l}\text { Milium } \\
\text { effusum }\end{array}$ & 14.43 & Carex pilosa & 24.45 & Carex pilosa & 22.99 & Carex pilosa & 16.56 \\
\hline & $\begin{array}{l}\text { Meehania } \\
\text { urticifolia }\end{array}$ & 13.26 & $\begin{array}{l}\text { Aegopodium } \\
\text { alpestre }\end{array}$ & 10.54 & $\begin{array}{l}\text { Meehania } \\
\text { urticifolia }\end{array}$ & 10.69 & $\begin{array}{l}\text { Aegopodium } \\
\text { alpestre }\end{array}$ & 10.99 \\
\hline & Carex pilosa & 11.93 & $\begin{array}{l}\text { Filipendula } \\
\text { palmata }\end{array}$ & 10.20 & $\begin{array}{l}\text { Aegopodium } \\
\text { alpestre }\end{array}$ & 10.26 & $\begin{array}{l}\text { Filipendula } \\
\text { palmata }\end{array}$ & 10.59 \\
\hline & $\begin{array}{l}\text { Aegopodium } \\
\text { alpestre }\end{array}$ & 10.30 & $\begin{array}{l}\text { Brachybotrys } \\
\text { paridiformis }\end{array}$ & 7.34 & $\begin{array}{l}\text { Filipendula } \\
\text { palmata }\end{array}$ & 9.67 & $\begin{array}{l}\text { Carex } \\
\text { callitrichos }\end{array}$ & 9.64 \\
\hline & $\begin{array}{l}\text { Filipendula } \\
\text { palmata }\end{array}$ & 10.25 & $\begin{array}{l}\text { Meehania } \\
\text { urticifolia }\end{array}$ & 5.73 & $\begin{array}{l}\text { Brachybotrys } \\
\text { paridiformis }\end{array}$ & 5.81 & $\begin{array}{l}\text { Meehania } \\
\text { urticifolia }\end{array}$ & 6.38 \\
\hline & Others & 39.83 & Others & 41.74 & Others & 40.58 & Others & 45.84 \\
\hline \multirow[t]{4}{*}{ September } & Carex pilosa & 17.66 & Carex pilosa & 33.06 & Carex pilosa & 27.94 & Carex pilosa & 22.89 \\
\hline & $\begin{array}{l}\text { Aegopodium } \\
\text { alpestre }\end{array}$ & 16.34 & $\begin{array}{l}\text { Aegopodium } \\
\text { alpestre }\end{array}$ & 11.01 & $\begin{array}{l}\text { Meehania } \\
\text { urticifolia }\end{array}$ & 11.90 & $\begin{array}{l}\text { Filipendula } \\
\text { palmata }\end{array}$ & 16.76 \\
\hline & $\begin{array}{l}\text { Milium } \\
\text { effusum }\end{array}$ & 12.75 & $\begin{array}{l}\text { Filipendula } \\
\text { palmata }\end{array}$ & 10.79 & $\begin{array}{l}\text { Aegopodium } \\
\text { alpestre }\end{array}$ & 10.64 & $\begin{array}{l}\text { Aegopodium } \\
\text { alpestre }\end{array}$ & 16.64 \\
\hline & $\begin{array}{l}\text { Meehania } \\
\text { urticifolia }\end{array}$ & 12.46 & $\begin{array}{l}\text { Athyrium } \\
\text { multidentatum }\end{array}$ & 7.93 & $\begin{array}{l}\text { Filipendula } \\
\text { palmata }\end{array}$ & 9.67 & $\begin{array}{l}\text { Urtica } \\
\text { angustifolia }\end{array}$ & 16.28 \\
\hline
\end{tabular}


Table 2 The top 5 herbs with relative importance value in different months (Continued)

\begin{tabular}{|c|c|c|c|c|c|c|c|c|}
\hline \multirow[t]{2}{*}{ Month } & \multicolumn{2}{|l|}{ CK } & \multicolumn{2}{|l|}{ LT } & \multicolumn{2}{|l|}{ MT } & \multicolumn{2}{|l|}{ HT } \\
\hline & Species & $\begin{array}{l}\text { Importance } \\
\text { value (\%) }\end{array}$ & Species & $\begin{array}{l}\text { Importance } \\
\text { value (\%) }\end{array}$ & Species & $\begin{array}{l}\text { Importance } \\
\text { value (\%) }\end{array}$ & Species & $\begin{array}{l}\text { Importance } \\
\text { value (\%) }\end{array}$ \\
\hline & $\begin{array}{l}\text { Cardamine } \\
\text { leucantha }\end{array}$ & 8.76 & $\begin{array}{l}\text { Carex } \\
\text { remotiuscula }\end{array}$ & 6.88 & $\begin{array}{l}\text { Athyrium } \\
\text { multidentatum }\end{array}$ & 5.61 & $\begin{array}{l}\text { Meehania } \\
\text { urticifolia }\end{array}$ & 5.67 \\
\hline & Others & 32.03 & Others & 30.33 & Others & 34.24 & Others & 21.76 \\
\hline \multirow[t]{6}{*}{ October } & Carex pilosa & 40.12 & Carex pilosa & 58.27 & Carex pilosa & 47.63 & Carex pilosa & 39.57 \\
\hline & $\begin{array}{l}\text { Meehania } \\
\text { urticifolia }\end{array}$ & 21.20 & $\begin{array}{l}\text { Aegopodium } \\
\text { alpestre }\end{array}$ & 15.78 & $\begin{array}{l}\text { Aegopodium } \\
\text { alpestre }\end{array}$ & 19.20 & $\begin{array}{l}\text { Aegopodium } \\
\text { alpestre }\end{array}$ & 17.47 \\
\hline & $\begin{array}{l}\text { Aegopodium } \\
\text { alpestre }\end{array}$ & 17.57 & $\begin{array}{l}\text { Meehania } \\
\text { urticifolia }\end{array}$ & 10.89 & $\begin{array}{l}\text { Carex } \\
\text { remotiuscula }\end{array}$ & 14.91 & $\begin{array}{l}\text { Carex } \\
\text { callitrichos }\end{array}$ & 13.60 \\
\hline & $\begin{array}{l}\text { Milium } \\
\text { effusum }\end{array}$ & 8.08 & Carex callitrichos & 5.38 & $\begin{array}{l}\text { Meehania } \\
\text { urticifolia }\end{array}$ & 10.24 & $\begin{array}{l}\text { Meehania } \\
\text { urticifolia }\end{array}$ & 8.86 \\
\hline & $\begin{array}{l}\text { Cardamine } \\
\text { leucantha }\end{array}$ & 5.68 & $\begin{array}{l}\text { Filipendula } \\
\text { palmata }\end{array}$ & 4.20 & Carex callitrichos & 2.93 & $\begin{array}{l}\text { Carex } \\
\text { remotiuscula }\end{array}$ & 8.60 \\
\hline & Others & 7.35 & Others & 5.48 & Others & 5.09 & Others & 11.90 \\
\hline
\end{tabular}

Carex remotiuscula, Aegopodium alpestre and Filipendula palmata. The order of importance values in the moderate thinning was Carex pilosa $>$ Filipendula palmata $>$ Carex remotiuscula $>$ Meehania urticifolia $>$ Aegopodium alpestre, and the importance values of the plots with heavy thinning were Carex pilosa $>$ Filipendula palmata $>$ Aegopodium alpestre $>$ Meehania urticifolia $>$ Carex remotiuscula. In the moderate and heavy thinning, the sum of the importance values of these plants was $54.94 \%$ and $60.25 \%$, respectively. The herb plants with importance values greater than $1 \%$ were 21 and 22 species and accounted for $92.47 \%$ and $93.50 \%$ of all herb species, respectively. 38, 39, 46 and 36 species of herbs were found in control, light thinning, moderate thinning and heavy thinning respectively. Compared with the control, moderate thinning significantly increased the number of herbs. This is due to the good light under the forest and the invasion of light loving herbs species after moderate thinning, and there are more shade environment under the forest and more shade loving herbs are retained, which makes the light loving and shade loving species co-exist, resulting in a relatively large number of species. After heavy thinning, the shade environment under the forest is less and the light condition is excellent, which is especially suitable for the survival of photophilous herbs, but the loss of photophilous species.

In August, the top 5 importance values of herbaceous plants in the control were Milium effusum, Meehania urticifolia, Carex pilosa, Aegopodium alpestre and Filipendula palmata. The sum of the importance values was $60.17 \%$, and there were 15 species with the importance value greater than 1, accounting for $90.59 \%$ of all herb species. The top 5 importance values of herbaceous plants in the light thinning were Carex pilosa, Aegopodium alpestre, Filipendula palmata, Brachybotrys paridiformis and Meehania urticifolia, with the sum of the important values of $58.26 \%$. There were 19 species with the importance value greater than $1 \%$, accounting for $94.23 \%$ of all herb species. The top 5 important values of herbaceous plants in the moderate thinning were Carex pilosa, Meehania urticifolia, Aegopodium alpestre, Filipendula palmata and Brachybotrys paridiformis. The sum of the important values was $59.42 \%$, and there were 16 species with the importance value greater than $1 \%$, accounting for $87.55 \%$ of all herb species. The top 5 important values of herbaceous plants in the heavy thinning were Carex pilosa, Aegopodium alpestre, Filipendula palmata, Carex callitrichos and Meehania urticifolia. The sum of the importance values was $54.16 \%$, and there were 21 species with the importance value greater than $1 \%$, accounting for $95.51 \%$ of all herb species. Among the top 5 species of herbs in different thinning plots, there are 4 common species, namely Carex pilosa, Meehania urticifolia, Aegopodium alpestre and Filipendula palmata. From the important values of these 4 species, the important values of Carex pilosa increased significantly after thinning, while that of Meehania urticifolia decreased. Aegopodium alpestre and Filipendula palmata were relatively consistent in different plots, and there was no significant change.

In September, the top 5 importance values of herbaceous plants in the control were Carex pilosa, Aegopodium alpestre, Milium effusum, Meehania urticifolia, and Cardamine leucantha, the sum of the important values was $67.97 \%$. There were 11 species of herbs with importance values more than $1 \%$, accounting for $94.00 \%$ of all herb species. The top 5 important values of herbaceous plants in the light thinning were Carex pilosa, Aegopodium alpestre, Filipendula palmata, Athyrium multidentatum and Carex remotiuscula. The sum of the important values was $69.67 \%$. There were 15 
species with importance values greater than $1 \%$, accounting for $96.65 \%$ of all herb species. The top $5 \mathrm{im}$ portance values of herbaceous plants in the moderate thinning were Carex pilosa, Meehania urticifolia, Aegopodium alpestre, Filipendula palmata and Athyrium multidentatum. The sum of the important values was $65.76 \%$. There were 16 species with importance value more than $1 \%$, accounting for $92.82 \%$ of all herb species. The top 5 importance values of herbaceous plants in the heavy thinning were Carex pilosa, Filipendula palmata, Aegopodium alpestre, Urtica angustifolia and Meehania urticifolia. The sum of the important values was $78.24 \%$. There were 13 species with the importance value greater than $1 \%$, accounting for $99.14 \%$ of all herb species. 23, 21, 25 and 14 species of herbs were found in the control, light thinning, moderate thinning and heavy thinning, respectively. This is due to the fact that more photophilous species, such as Impatiens noli-tangere, have invaded the plots after heavy thinning. The earlier invasive species will occupy a wide area in the sample plot, and prevent the invasion of other species. Consequently, the number of species will decrease after heavy thinning. With the coming of autumn, the number of photophilous species in the heavy thinning plots in September was lower because of their higher individuals and more easily withered and died.

In October, the top 5 importance values of herbaceous plants in the control were Carex pilosa, Meehania urticifolia, Aegopodium alpestre, Milium effusum and Cardamine leucantha, the sum of the importance value was $92.65 \%$. There are 8 species with importance value greater than $1 \%$, accounting for $98.60 \%$ of all herb species. The top 5 importance values of herbaceous plants in the light thinning were Carex pilosa, Aegopodium alpestre, Meehania urticifolia, Carex callitrichos and Filipendula palmata. The sum of the important values was $94.52 \%$, and there were 7 species with the importance value greater than $1 \%$, accounting for $99.32 \%$ of all herb species. The top 5 importance values of herbaceous plants in the moderate thinning were Carex pilosa, Aegopodium alpestre, Carex remotiuscula, Meehania urticifolia and Carex callitrichos. The sum of the important values of was $94.91 \%$. There were 6 species with importance value greater than $1 \%$, accounting for $97.38 \%$ of all herb species. The top 5 importance values of herbaceous plants in the heavy thinning were Carex pilosa, Aegopodium alpestre, Carex callitrichos, Meehania urticifolia, and Carex remotiuscula. The sum of the important values was $88.10 \%$. There were 8 species with important value greater than $1 \%$, accounting for $99.34 \%$ of all herb species. There were $10,8,10$ and 9 species of herbs in the control, light thinning, moderate thinning and heavy thinning, respectively. There was no significant difference in the number of species in different plots, and the species in different plots were almost the same.

\section{Seasonal changes in diversity index}

Calculation of diversity index showed that there were significant variations $(P<0.05)$ in different thinning. Except for the control, which showed an increasing trend from May to June, the Margalef index showed a similar trend in all plots in other months (Fig. 1a). It gradually decreased from May to July, increased from July to August, and then fell rapidly from August to October. The Margalef index of different treatments showed various patterns in different months with moderate thinning $>$ heavy thinning $>$ light thinning $>$ control in May, and control $>$ moderate thinning $>$ light thinning $>$ heavy thinning from June to August. From August to October, the Margalef index of the four plots all showed a significant decreasing trend with control $>$ light thinning $>$ moderate thinning > heavy thinning.

In the four treatments, the Shannon-Wiener index and Simpson index had similar patterns (Fig. 1b and c). The Shannon-Wiener index and Simpson index gradually decreased from May to July, increased gradually from July to August, and then decreased sharply. In June, July and September, the Shannon-Wiener index and Simpson index in the control were higher than the other three thinning treatments. In May, August and October, the Shannon-Wiener index and Simpson index of the four plots were relatively the same.

Throughout the growing season, the Pielou index was roughly in the shape of an inverted "N" (Fig. 1d), namely it had a high value at the beginning of growth, a low value in June or July, and the second peak in August, and then it decreased sharply. The Pielou index of the control was generally higher than that of the other thinning treatments. The control plot and the heavy thinning showed the first decrease in June, while the light and moderate thinning showed the first decrease in July.

\section{Effect of thinning on biomass Seasonal changes in biomass}

In May, thinning can promote the increase of total biomass, above-ground biomass and belowground biomass of herbaceous plants, but there were no significant differences among thinning treatments. Total biomass and above-ground biomass were the largest in light thinning, and the belowground biomass was the largest in moderate thinning. In terms of root-to-shoot ratio, the moderate thinning was significantly higher than the other three treatments, and the light and heavy thinning were not significantly different from the control. Compared with the control, the number of herbaceous plants decreased after light thinning, but the difference was not obvious. 

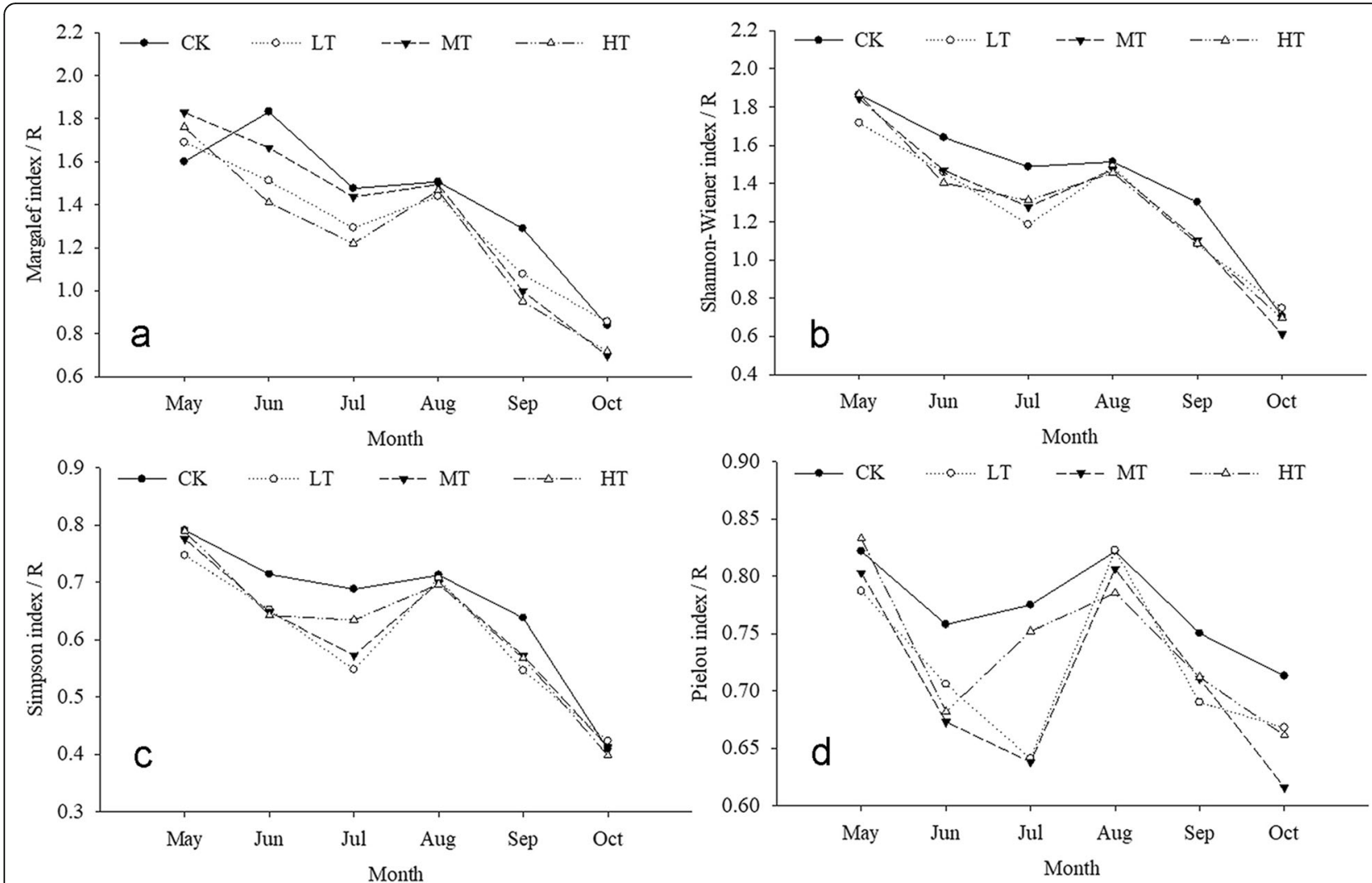

Fig. 1 Monthly change of herbaceous plant diversity index

Moderate and heavy thinning significantly increased the number of herbaceous plants. In terms of average height and total coverage, moderate thinning was significantly higher than that of light thinning.

The biomass of herbaceous plants increased in July compared with May. Compared with the control, thinning promoted the increase of total biomass, above- and belowground biomass. Among them, the total biomass, above- and belowground biomass were significantly higher in heavy thinning than those of the control. The difference between moderate thinning and the control was not significant. In terms of root-shoot ratio, the difference between the four treatments was not significant, indicating that thinning intensity did not change the biomass allocation between the above- and belowground parts. Thinning increased the number of plants, and the number increased with increasing thinning intensity. The average height of herbaceous plants after thinning decreased, but the difference was not significant. In addition, thinning increased the total coverage of herbaceous plants. The coverage was significantly higher in the heavy thinning than that in the control, while the light and moderate thinning were not significantly different from the control.

Compared with the control, thinning significantly increased the total herb biomass and belowground biomass in September. Heavy thinning rather than light thinning and moderate thinning significantly increased above-ground biomass. After thinning, the root-shoot ratio increased significantly, but the difference in the root-shoot ratio was not significant among light, moderate and heavy thinning, indicating that thinning changed the distribution of above- and belowground biomass of herbaceous plants. The nutrients were mostly allocated to the belowground part, but the thinning intensity did not change the distribution of plant biomass between above- and belowground parts. Thinning increased the number of herbaceous plants, and the number of herbaceous plants in the moderate and the heavy thinning was significantly higher than that in the control. The average height of herbs decreased after thinning, which was evident in light thinning. Thinning significantly increased the total coverage of herbs, but there were no significant differences among light, moderate and heavy thinning.

The correlation analysis of the biomass in different months is shown in Fig. 2. In May, the total biomass significantly correlated with the number, average height, and the total coverage, but it did not significantly correlate with the root-shoot ratio. Above-ground biomass was positively correlated with the number, average height and total coverage, but not correlated with the 


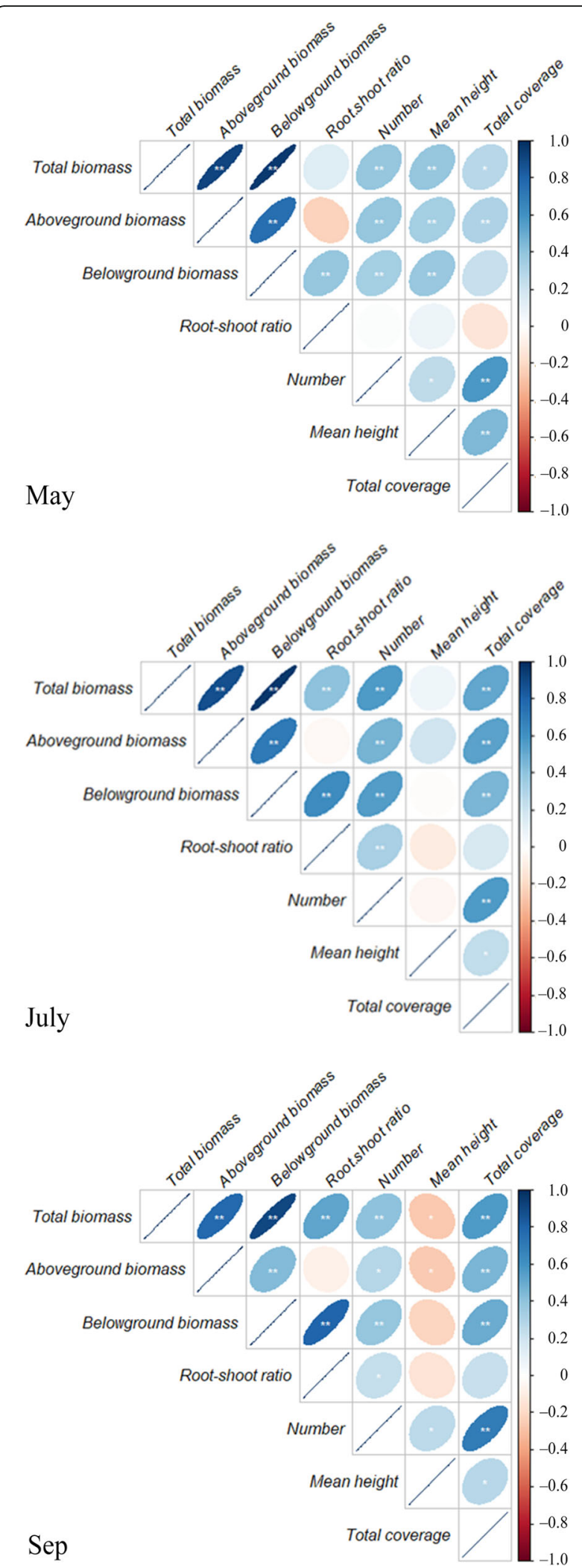

Fig. 2 Correlation of various biomasses of herbaceous plants in different months root-shoot ratio. Belowground biomass was positively correlated with root-shoot ratio, the number and average height, but did not change with the total coverage.

In July, the number and total coverage of herbaceous plants were positively correlated with total biomass, above- and belowground biomass. The average height of herbaceous plants did not correlate with total biomass, above- and belowground biomass. The root-shoot ratio significantly correlated with total biomass and belowground biomass.

In September, the root-shoot ratio positively correlated with total biomass and belowground biomass. The number of herb plants had a significantly and positively correlation with total biomass and belowground biomass. The average height of herb plants was significantly and negatively correlated with the total biomass and above-ground biomass. The total coverage of herb plants was positively related to the total biomass, above- and belowground biomass.

It was found that the herb biomass was different over time (Table 3). In the control, the total biomass, aboveand belowground biomass all showed their maximum in July. After thinning, the total biomass, above- and belowground biomass all gradually increased over time and reached their maximum in September. In the thinning treatments, the total biomass, above- and belowground biomass in September were significantly higher than those in May.

\section{Correlations between diversity and biomass}

The correlation analysis between herb biomass and diversity index in different months is shown in Fig. 3. In May, total herb biomass, above- and below ground biomass were significantly and positively correlated with Shannon-Wiener index, Simpson index, and Pielou index. The correlation between herb biomass and diversity index in July and September was not significant. Compared with May, the relationship between species diversity and biomass were changed, indicating that seasonal changes will change the relationships.

\section{Discussion}

\section{Importance values variation}

Forest thinning, as an important forest management practice, is an important way to change the composition and structure of the forest, adjust forest density, and improve the understory environmental conditions. It will directly affect the composition and diversity of understory vegetation, and influence tree growth and community stability (Zhang and Tang 2008). The importance values of each species varied significantly among 
Table 3 Biomass of herbaceous plants in different months

\begin{tabular}{|c|c|c|c|c|c|c|c|c|}
\hline Month & Treatments & $\begin{array}{l}\text { Total } \\
\text { biomass } \\
\left(\mathrm{g} \cdot \mathrm{m}^{-2}\right)\end{array}$ & $\begin{array}{l}\text { Aboveground } \\
\text { biomass } \\
\left(\mathbf{g} \cdot \mathrm{m}^{-2}\right)\end{array}$ & $\begin{array}{l}\text { Belowground } \\
\text { biomass } \\
\left(\mathrm{g} \cdot \mathrm{m}^{-2}\right)\end{array}$ & $\begin{array}{l}\text { Root-shoot } \\
\text { ratio }\end{array}$ & $\begin{array}{l}\text { Number per } \\
\mathrm{m}^{2}\end{array}$ & $\begin{array}{l}\text { Mean height } \\
(\mathrm{cm})\end{array}$ & $\begin{array}{l}\text { Total coverage } \\
\text { (\%) }\end{array}$ \\
\hline \multirow[t]{4}{*}{ May } & CK & $113 \pm 10 a$ & $53 \pm 4 a$ & $59 \pm 7 a$ & $1.11 \pm 0.10 \mathrm{a}$ & $216 \pm 12 a$ & $11.95 \pm 0.36 \mathrm{ab}$ & $68.75 \pm 3.70 \mathrm{ab}$ \\
\hline & LT & $194 \pm 12 b$ & $86 \pm 5 b$ & $109 \pm 8 b c$ & $1.29 \pm 0.06 a$ & $198 \pm 11 a$ & $11.14 \pm 0.36 a$ & $59.60 \pm 2.77 a$ \\
\hline & MT & $188 \pm 21 b$ & $71 \pm 10 a b$ & $117 \pm 12 b$ & $1.86 \pm 0.17 b$ & $275 \pm 18 b$ & $12.44 \pm 0.48 b$ & $72.75 \pm 3.55 b$ \\
\hline & HT & $163 \pm 15 b$ & $76 \pm 8 b$ & $88 \pm 8 c$ & $1.18 \pm 0.09 a$ & $265 \pm 19 b$ & $12.09 \pm 0.41 \mathrm{ab}$ & $67.53 \pm 4.46 a b$ \\
\hline \multirow[t]{4}{*}{ July } & CK & $207 \pm 16 a$ & $104 \pm 11 a$ & $104 \pm 8 a$ & $1.05 \pm 0.08 a$ & $122 \pm 14 a$ & $30.14 \pm 1.18 a$ & $65.63 \pm 3.13 a$ \\
\hline & LT & $240 \pm 13 a$ & $108 \pm 6 a$ & $132 \pm 9 a b$ & $1.24 \pm 0.08 a$ & $175 \pm 20 a b$ & $26.89 \pm 1.88 a$ & $70.20 \pm 3.70 a$ \\
\hline & MT & $236 \pm 19 a$ & $107 \pm 9 a$ & $128 \pm 12 a$ & $1.22 \pm 0.09 a$ & $191 \pm 18 b$ & $28.07 \pm 1.20 a$ & $70.65 \pm 2.98 a$ \\
\hline & HT & $339 \pm 53 b$ & $154 \pm 16 b$ & $185 \pm 39 b$ & $1.12 \pm 0.13 a$ & $219 \pm 29 b$ & $28.79 \pm 1.34 a$ & $81.67 \pm 3.89 b$ \\
\hline \multirow[t]{4}{*}{ September } & CK & $161 \pm 8 a$ & $85 \pm 3 a$ & $76 \pm 5 a$ & $0.89 \pm 0.05 a$ & $109 \pm 10 a$ & $25.12 \pm 0.75 a$ & $58.30 \pm 2.24 a$ \\
\hline & LT & $273 \pm 22 b$ & $112 \pm 7 a$ & $161 \pm 17 b$ & $1.43 \pm 0.12 b$ & $134 \pm 26 a b$ & $21.20 \pm 1.90 b$ & $70.06 \pm 3.96 b$ \\
\hline & MT & $289 \pm 30 b$ & $113 \pm 8 a$ & $176 \pm 23 b c$ & $1.51 \pm 0.13 b$ & $181 \pm 16 b$ & $24.62 \pm 0.98 a b$ & $76.80 \pm 3.28 b$ \\
\hline & HT & $418 \pm 43 c$ & $192 \pm 28 b$ & $225 \pm 31 c$ & $1.41 \pm 0.25 b$ & $180 \pm 43 b$ & $21.47 \pm 1.36 a b$ & $78.13 \pm 4.93 b$ \\
\hline
\end{tabular}

different thinning treatments. The reason may be that the growth of overstorey changes with season, which in turn causes changes in the understory environment. The importance values of species in different treatments showed similar patterns with seasonal changes. The importance values of early spring plant were greater in May, and the top 5 importance values of various treatments were Anemone amurensis, Hylomecon japonica, Anemone raddeana, and Corydalis ambigua. Furthermore, these plants constitute the main body of herbaceous plants under the broad-leaved Korean pine forest in early spring. At this time, the overstorey has not yet reached canopy closure, the understory has sufficient sunlight, and the understory temperature continues to rise. In addition to early spring plants, other herbaceous plants have also sprouted in large numbers, so there are more species in May (Chen and Matter 2017; Kleinn et al. 2020). In June, the trees grow fast, but the overstorey is not completely closed. The light intensity of understory gradually decreases, and the plants wither and die in early spring. Except for the control, the number of species significantly decreased in other thinning treatments. At this time, Carex pilosa, Aegopodium alpestre, Meehania urticifolia, and Filipendula palmata replaced early spring plants as the dominant species of understory herbs, and ferns also showed greater advantages due to their vigorous growth (Gao et al. 2019). The overstory grows fast in July. The canopy density is relatively high, and the understory light intensity is low. At this time, the understory is mainly covered by shadetolerant species such as Carex pilosa, Carex remotiuscula, Carex callitrichos, Carex siderosticta, Meehania urticifolia, Laportea bulbifera, Urtica angustifolia. As precipitation begins to increase, understory wet plants grow quickly, leading to an increase in the number of species (Hulík and Douda 2017). The overstory reaches its growth peak in August, and the canopy closure continues to increase, resulting in a continuous decrease in understory light intensity. Early spring plants and some early summer plants withered and died, and the number of understory herbaceous species declined significantly, but the dominant species did not change (Gong et al. 2016). The temperature drops significantly in September, and the overstory stops growing, some tall trees begin to defoliate, and the canopy closure is reduced. At this time, most of the herbaceous plants also stop the growth of the above-ground parts and enter the nutrient reserve period, which causes a significant decrease in the number of species. Understory herbaceous plants still consist of dominant species such as Carex pilosa, Aegopodium alpestre and Meehania urticifolia (Wu et al. 2018). In October, the Changbai Mountain area has entered the end of autumn. Although most of the trees in the upper layer of the canopy have fallen leaves, there is sufficient sunlight understory. But due to the low temperature, most of the herbaceous plants have withered and died, causing the number of species to drop to the lowest value in the growing season (Dai et al. 2013). Based on the data of the entire growing season, the top herbaceous plants in the various treatments are mainly composed of Carex pilosa, Aegopodium alpestre, Meehania urticifolia and Filipendula palmata, indicating that these species have strong adaptability and a wide ecological range.

\section{Herbaceous plant species variation}

The monthly changes in the number of herbaceous plant species in different thinning treatments indicate that the number of species in the thinning in May is higher than that in the control. This may be due to the increased 


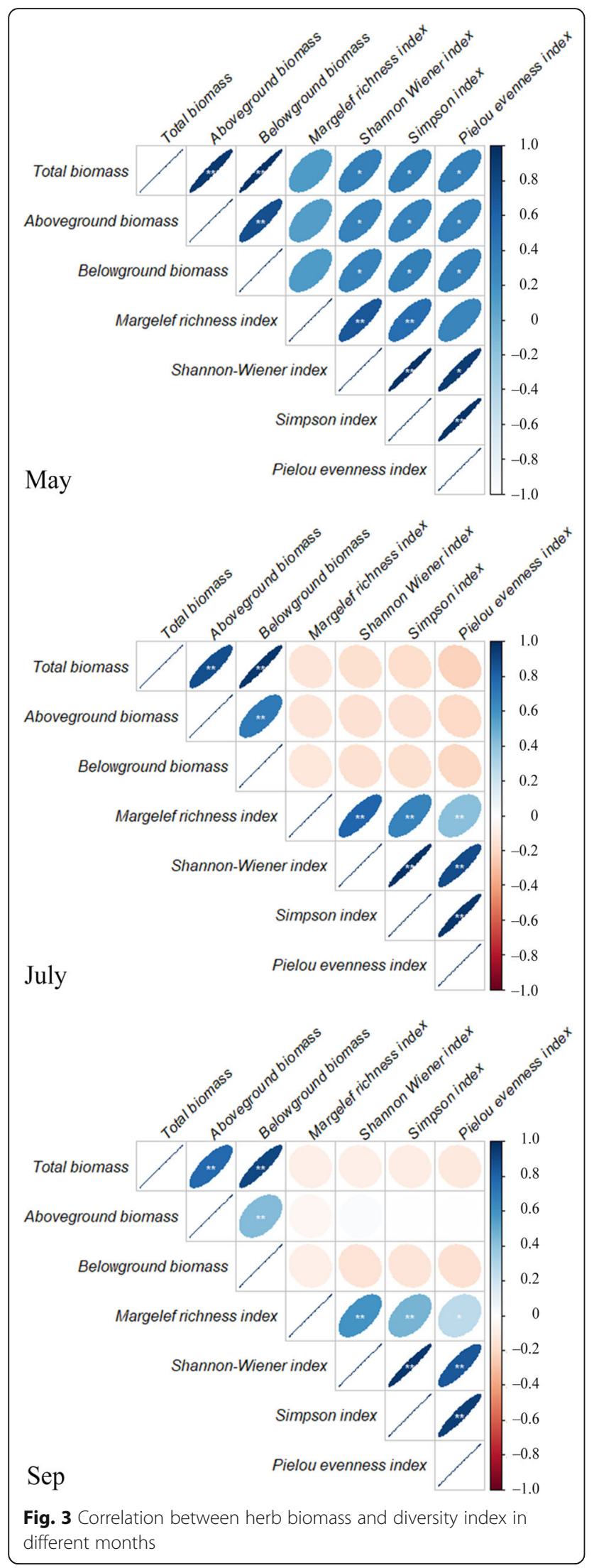

understory light intensity after thinning, which leads to the advance of plant phenology (Ye et al. 2015). The number of species in the thinning treatments decreased in June. This is due to the advance of the phenological period after thinning that causes some early spring short-lived plants to wither and die, resulting in a decrease in the number of species in the thinned treatments ( $\mathrm{Li}$ et al. 2006). From July to September, the number of species in the four treatments gradually decreased. This is because July is the rainy season in this area. The soil under the forest is moist and the temperature is high, which is most suitable for plant growth. Therefore, the number of species in July reached the maximum. Although the enhancement of understory light intensity might have caused the death of some shade-tolerant species in moderate thinning, heliophile will quickly invade the site, leading to species reaching the maximum in the moderate thinning during this period. Although light thinning may not significantly increase light intensity, the thinning will form gaps, which will lead to the death of some rare shade-tolerant herbaceous plants, and the heliophile cannot invade the plot, resulting in the decrease of species numbers. In the heavy thinning treatment, the understory sunlight is significantly enhanced and there are more gaps, causing the death of most of the shade-tolerant herbaceous plants. Although the heliophile can invade the site, they cannot compensate for the death number of shade-tolerant plant, resulting in a significant decrease in species numbers (Ding et al. 2016). The understory temperature and light intensity of the four treatments are very low in October, and the understory environmental conditions are roughly the same. Most of the herbaceous plants withered and died, and only a few herbs with strong cold tolerance could survive (Small and McCarthy 2002).

\section{Herbaceous plant individuals number variation}

Throughout the growing season, the number of individual plants in the heavy thinning is the largest, indicating that thinning can promote the increase in the number of individual plants. This is due to the increase in the intensity of thinning, which leads to the increase of understory light intensity, subsequently promoting the increase of understory herb plants (Westerband and Horvitz 2017; Didion 2020). The number of individuals in the moderate thinning was higher than that in the heavy thinning in July. This is due to the presence of large herb plants in the heavy thinning, occupying a larger space under the forest, resulting in the death of some small one (Zhang et al. 2019). The number of individual plants in the control showed a decreasing trend. This was because most of the control in May were early spring plants. Although the early spring plants are small, there are more individuals on the same stem, so the 
number of individuals was the largest. Early spring plants gradually die from June to August, early summer plants and late summer plants dominant the herbaceous plants. These plants are relatively large, occupying more space understory, resulting in a decrease in the number of individual plants. The overstory defoliate in September, the increase in understory light intensity increases the ground temperature, and the secondary growth of some plants leads to an increase in the number of individuals. The temperature gradually decreases in October, and most understory herbs are not cold-resistant, and will gradually wither and die, leading to a decrease in the number of individuals (Grant et al. 2019). The increase in the number of individual plants in May and June after thinning is due to the increase in understory light and the increase in understory temperature due to thinning, which advances the phenological period of plants. There are two types of plants including early spring plants and early summer plants in June (especially in heavy thinning). At this time, the plant individuals are small, and the understory space can meet the needs of plant growth. Therefore, the number of individual plants tends to increase. After June, the size of individual plants gradually increases after June, resulting in insufficient understory space and the competition causing the death of some individuals, which led to a decrease in the number of individuals (Li et al. 2017).

\section{Herbaceous plant biomass variation}

The total biomass, aboveground biomass and belowground biomass of the thinning treatments were greater than those in the control, indicating that thinning can promote the biomass growth of understory herbaceous plants. The greater the thinning intensity, the faster the plant biomass will grow. This is because thinning can significantly improve the understory light environment, thereby promoting biomass growth of understory herbs (Tinya and Ódor 2016). The plant heights of the light thinning and the control showed a peak curve, and the plant heights of the heavy and moderate thinning showed a double-peak curve. This is because July is the rainy season and the temperature is high, and the environmental conditions are moderate. Both overstory and understory entered the vigorous growth period, and the average height of the herbs reached the maximum. In August, as the stand canopy density increase, the understory light of the light thinning and the control was relatively poor, some tall herbs gradually withered and died due to insufficient growth. The light environment of the moderate and the heavy thinning improved significantly after thinning. After the highest canopy closure time in August, understory herbaceous plants have a significant high growth. For example, the heights of Carex pilosa, ferns, and Impatiens noli-tangere, Veratrum nigrum and other plants in the moderate and heavy thinning were significantly higher than those in the light thinning and the control (Sun et al. 2017).

The diversity of herbaceous plants is an important indicator of the succession and development of forests. This study only studied four-intensity thinning in nearmature forests. In order to better reflect the effects of thinning on the understory environment, herbaceous plant diversity and biomass, therefore, it is necessary to further carry out relevant experiments in forest with different development stages and stand characteristics. It is also a necessity to analyze the impact of thinning on forest species diversity and biomass, guide forest management and accelerate the development of secondary forests to primary forests. In addition, this study also demonstrates that the species diversity and biomass of shrubs will also be affected by thinning. In the future, research can be conducted on the impact of thinning on the species diversity and biomass of shrubs.

\section{Conclusions}

The changes of biodiversity in the herb layer under the coniferous and broad-leaved mixed forest in Changbai Mountain were mainly affected by seasons. However, thinning changed the light environment in the forest, which could improve the plant diversity and biomass of herb layer in a short time. Moderate thinning had the most significant effect on the number of species, and the number of individual plants, average height and total coverage of plants increased significantly in all months of the growing season. With the increase of thinning intensity, the biomass of herb layer increased accordingly. Total herb biomass, above- and belowground biomass showed positive correlations with Shannon-Winner index, Simpson index and Pielou index in May. The findings provide theoretical basis and reference for reasonable thinning and tending in coniferous and broadleaved mixed forests.

\section{Acknowledgements}

We would like to thank the two anonymous reviewers and the associate editor for their constructive comments that greatly helped improving the manuscript.

\section{Authors' contributions}

Gerong Wang designed the study and developed the main hypotheses, Mo Zhou and Mengjia Wu collected and prepared the data, Naiqian Guan, Yuwen Wang, Runhua Jiang and Zhiyu Liu analyzed the data, Fucai Xia and Yue Sun drafted the manuscript. All authors commented preliminary versions of the manuscript and contributed to improve the final version. The author(s) read and approved the final manuscript.

\section{Funding}

This work was financially supported by a grant from the National Key Research and Development Program of China (2017YFC0504102) and the Science and Technology Program of Jilin Provincial Education Department (JJKH20180349KJ). 


\section{Availability of data and materials}

The datasets used and/or analysed during the current study are available from the corresponding author on reasonable request.

\section{Declarations}

Ethics approval and consent to participate

Not applicable.

\section{Consent for publication}

Not applicable.

\section{Competing interests}

The authors declare that they have no competing interests.

\section{Author details}

'Key Laboratory of State Forestry Administration on Conservation and Efficient Utilization of Precious and Rare Forest Resource in Changbai Mountain, Forestry College, Beihua University, 132013 Jilin, China. ${ }^{2}$ West Campus of Hebei Agricultural University, 2596 Lekai South Street, Lianchi District, 071000 Baoding, China.

\section{Received: 26 December 2020 Accepted: 14 May 2021}

\section{Published online: 02 August 2021}

\section{References}

An Y, Ding GD, Liang WJ, Gao GL, He Y, Wei B, Bao YF, Bao B (2012) Effects of thinning on the growth and the development of undergrowth of Pinus tabulaeformis plantation in rocky mountain area of north China. Res Soil Water Conserv 19(4):86-90 (in Chinese)

Chen HY, Matter SF (2017) Quantification of changes in light and temperature associated with invasive Amur Honeysuckle (Lonicera maackii). Am Midl Nat 177(1):143-152

Dai LM, Jia J, Yu DP, Lewis BJ, Zhou L, Zhou WM, Zhao W, Jiang LH (2013) Effects of climate change on biomass carbon sequestration in old-growth forest ecosystems on Changbai Mountain in Northeast China. Forest Ecol Manag 300:106-116

Didion M (2020) Extending harmonized national forest inventory herb layer vegetation cover observations to derive comprehensive biomass estimates. For Ecosyst 7:16. https://doi.org/10.1186/s40663-020-00230-7

Ding Y, Lu XH, Zang RG, Huang JH, Yang XS, Zhou YD, Huang Y, Feng YZ (2016) Effects of tending on the community structure and species diversity of a tropical natural secondary forest. For Res 29(4):480-486 (in Chinese)

Gao GZ, Jie DM, Li DH, Li NN, Liu LD, Liu HY, Leng CC, Wang JY, Liu BJ, Li P (2019) Assessing modern arboreal phytolith sensitivity to vegetation variations in temperate forest regions. Boreas 48(3):731-745

Gong GT, Niu M, Mu CL, Chen JH, Li YQ, Zhu ZF, Zheng SW (2015) Impacts of different thinning intensities on growth of Cupressus funebris plantation and understory plants. Sci Silv Sin 51(4):8-15 (in Chinese)

Gong YB, Guo JB, Zhao XH, Yu SZ (2016) Herbaceous species diversity as related to soil factors in a Korean pine broadleaved forest of Jiaohe, Jilin Province. J Zhejiang A F Univ 33(4):620-628 (in Chinese)

Grant L, Johnson C, Thiessen C (2019) Evaluating the efficacy of translocation: maintaining habitat key to long-term success for an imperiled population of an at-risk species. Biodivers Conserv 28(10):2727-2743

Han J, Ying LX, Li GX, Shen ZH (2016) Spatial patterns of species diversity in the herb layer of early post-fire regeneration in mixed Pinus yunnanensis forests. Chin J Plant Ecol 40(3):200-211 (in Chinese)

Huang XC (2016) Effect of different thinning intensities on the growth of larch forest in eastern Liaoning Province. For Resour Manag (1):65-71 (in Chinese)

Huang YX, Xu X, Zhang LX, Song Y, Luo ZR (2016) Ten-years period of grass and small woody plant dynamics in a 5-ha evergreen forest plot in Baishanzu, Zhejiang Province. Biodivers Sci 24(12):1353-1363 (in Chinese)

Hulík J, Douda J (2017) Germination strategies of two dominant Carex species in a swamp alder forest: implications for restoration. Biologia 72(4):370-377

Kleinn C, Magnussen S, Nölke N, Magdon P, Álvarez-González JG, Fehrmann L, Pérez-Cruzado C (2020) Improving precision of field inventory estimation of aboveground biomass through an alternative view on plot biomass. For Ecosyst 7:57. https://doi.org/10.1186/s40663-020-00268-7
Lei XD, Lu YC, Zhang HR, Zhang ZL, Chen XG (2005) Effects of thinning on mixed stands of Larix olgensis, Abies nephrolepis and Picea jazoensis. Sci Silv Sin 41(4): 78-85 (in Chinese)

Li CY, Ma LY, Xu X (2006) Reviews on research progress of effect of tending on forest biodiversity. World For Res 19(6):27-32 (in Chinese)

Li LP, Mohammat A, Abdusalih N, Sarbay N, Wan HW (2017) Plant body size patterns of mountainous trees and grassland herbs in Xinjiang region, China. Biodivers Sci 25(11):1202-1212 (in Chinese)

Li RX, Ma HJ, Min JG, Hao JP, Guan QW (2012) Short-term and Long-term effects of thinning on the undergrowth diversity in the Pinus massoniana plantation. Ecol Environ Sci 21(5):807-812 (in Chinese)

Liu HY, Chen DL, Liu J, Zhao Y, Zhang YX, Guo JP (2014) Research on undergrowth plant diversity in Larix principis-rupprechtii plantation with different thinning levels-taking Longxing forest farm of Guandishan in Shanxi Province as an example. For Resour Manag (1):50-56 (in Chinese)

Liu Q, Sun Y, Wang GR, Cheng FS, Xia FC (2019) Short-term effects of thinning on the understory natural environment of mixed broadleaf-conifer forest in Changbai Mountain area, Northeast China. PeerJ 7:e7400. https://doi.org/10. 7717/peerj.7400

Rong JT, Huang QL, Zhang XH (2014) Effects of different selecting cutting on growth of natural broad-leaved Castanopsis carlesii forest. J Central South Univ For Technol 34(3):43-48 (in Chinese)

Small CJ, McCarthy BC (2002) Effects of simulated post-harvest light availability and soil compaction on deciduous forest herbs. Can J For Res 32(10):17531762

Sun Y, He HJ, Li L, Song CM, Wang FJ, Xia FC (2017) Biomass allocation and biomass allometric models of six early-summer herbs under the canopy of broad-leaved Korean pine forest during different growth periods in Jiaohe, Jilin Province. Acta Ecol Sin 37(19):6523-6533 (in Chinese)

Tinya F, Ódor P (2016) Congruence of the spatial pattern of light and understory vegetation in an old-growth, temperate mixed forest. Forest Ecol Manag 32: 84-92

Westerband AC, Horvitz CC (2017) Early life conditions and precipitation influence the performance of widespread understorey herbs in variable light environments. J Ecol 105(5):1298-1308

Whigham DF (2004) Ecology of woodland herbs in temperate deciduous forests. Ann Rev Ecol Evol Syst 35(1):583-621

Wu W, Li YH, Hu YM (2018) Effects of different management on plant diversity and vegetation structures in understory of forests. Ecol Environ Sci 27(7): 1369-1376 (in Chinese)

Ye GF, You LH, Lu CY, Lin WX, Luo MJ, Tan FL (2015) Global climate change and adaptive management of forest ecosystem. World For Res 28(1):1-6 (in Chinese)

You WZ, Zhao G, Zhang HD, Guo YT, Yan TW, Wei WJ, Mao YX (2015) Effects of thinning on growth of Mongolian oak (Quercus mongolica) secondary forests. Acta Ecol Sin 35(1):56-64 (in Chinese)

Zhang CY, Zhao XH, Zhao YZ (2009) Community structure in different successional stages in north temperate forests of Changbai Mountains, China. Chin J Plant Ecol 33(6):1090-1100 (in Chinese)

Zhang HY, Tang SZ (2008) Theory of ecology-based forest harvesting. Sci Silv Sin 44(10):127-131 (in Chinese)

Zhang LH, Qi JQ, Li TT, Yu SR, Zhang XY, Zhang R, Hao JF (2019) Effects of stand density on understory plant diversity and biomass in a Pinus massoniana plantation in Wenfeng Mountain, Xinjin County. Acta Ecol Sin 39(15):57095717 (in Chinese)

Zhou JY, Li R, Zhang WH, He JF (2012) Effects of thinning intensity on structure characteristics and spatial distribution of Quercus wutaishanica populations. Sci Silv Sin 48(4):149-155 (in Chinese)

Zhou ML, Zhang Q, Kang XG, Tian M, Yang YJ, Wang QJ (2015) Effects of different cuttings on growth of primary coniferous species in natural sprucefir forest. J Northeast For Univ 43(7):7-10, 30 (in Chinese) 